ANUVA Volume 2 (4): 387-392, 2018

Copyright (C2018, ISSN: 2598-3040 online

Available Online at: http://ejournal.undip.ac.id/index.php/anuva

\title{
Model Perilaku Pencarian Informasi Generasi Milenial
}

\author{
Yuli Rohmiyati ${ }^{1 *}$ \\ ${ }^{1}$ Prodi Ilmu Perpustakaan, Fakultas Ilmu Budaya, Universitas Diponegoro \\ Jl. Prof. Soedarto, SH, Kampus Tembalang, Semarang. Indonesia \\ *)Korespondensi : yulirohmiyati@gmail.com
}

\begin{abstract}
The purpose of this study is to describe the information behavior of the millennial generation in the city of Semarang. The research method used is a qualitative approach where data is collected by means of Focus Group Discussion and interviews. The results of this study are a new pattern of millennial information seeking behavior with the drivers, searching / browsing / surfing, selection, evaluation, share, repost, evaluation and response stages.
\end{abstract}

\section{Keywords: Information Search Behavior, Millennial Generation}

\begin{abstract}
Abstrak
Tujuan dari penelitian ini adalah menggambarkan perilaku informasi generasi millenial di Kota Semarang. Metode penelitian yang digunakan dengan pendekatan kualitatif yang mana data dikumpulkan dengan cara Focus Group Discussion dan wawancara. Hasil dari penelitian ini adalah sebuah pola baru perilaku pencarian informasi generasi millenial dengan tahapan Pendorong, Searching/ Browsing/ Surfing, Seleksi, Evaluasi, Share, Repost, Evaluasi dan Respon.
\end{abstract}

\section{Kata Kunci: Perilaku Pencarian Informasi, Generasi Millenial}

\section{Pendahuluan}

Generasi milenial merupakan generasi yang lahir pada tahun 1990, yang mana pada masa itu kehidupan masyarakat telah banyak menggunakan teknologi dalam proses kehidupannya. Seperti komputer yang banyak dimanfaatkan dalam proses pelayanan perpustakaan. Teknologi tersebut mulai mengambil alih proses layanan yang manual dan berpindah pada layanan terkomputerisasi. Atau seperti halnya juga rumah sakit yang mulai melayani pasiennya dengan bantuan komputer.

Ciri dari generasi ini adalah terbuka, mereka siap membuka pikiran dan membuka diri akan halhal baru yang menjadi trend terkini. Seperti kehadiran budaya korea yang berpenampilan rambut lurus dengan aksesoris yang beraneka ragam yang sangat berbeda dengan budaya Indonesia, para generasi millenial sangat terbuka dengan hal tersebut. Atau seperti kehadiran trend jilbab yang beraneka ragam, dari mulai motif hingga pada model pemakaiannya. Generasi millenial cenderung suka pamer akan eksistensi dirinya. Mereka mempunyai kebiasaan selfi atau memamerkan keadaan dirinya dan menyebarluaskan/ menshare keadaan dirinya pada masyarakat.

Kemudian mereka juga merupakan generasi yang bebas, dalam arti generasi millenial menyukai hal-hal baru dan suka untuk mencobanya. Dalam hal ini, generasi millenial merasa ada tantangan 
tersendiri ketika menerima hal baru, seperti selfie di tempat yang berbahaya ataupun mencoba suatu kreatifitas tertentu. Mereka suka jika semua kebebasan tersebut ada dalam kontrol sendiri. Maka yang dapat kita lihat sekarang bagaimana para generasi millenial banyak dan beramai-ramai memiliki ruang ajang kreatifitas mereka di dunia maya, seperti para youtuber ataupun blogger yang dengan bebas mereka menyampaikan ide dan menampilkan hobby, bakat dan kesukaan mereka.

Apa yang terlihat merupakan hal yang tak dapat dipungkiri. Generasi millenial memiliki perilaku berbeda dengan generasi sebelumnya. Dalam hal perilaku informasi saja, generasi millenial menggunakan alur dan cara yang berbeda. Perilaku informasi yang merupakan tindakan atau segala perwujudan tingkah laku manusia dalam menggunakan informasi dari mulai bagaimana kemunculan proses kebutuhan informasi hingga pada proses menemukan informasi serta bagaimana generasi tersebut menyeleksi dan mengevaluasi informasi sebelum akhirnya disebarluaskan dalam dunia maya.

Kajian tentang perilaku informasi yang telah ada memperlihatkan hal yang berbeda dengan apa yang dilakukan oleh generasi millenial saat ini. Perbedaan tersebut terlihat dari cara pencarian informasi, jenis informasi yang dicari, cara memunculkan informasi baru dengan media baru dan kemasan yang kreatif. Hal inilah yang akan dibahas sebagai bentuk kebaruan kecenderungan perilaku informasi generasi millenial.

\section{Rumusan masalah}

Rumusan masalah dalam penelitian ini adalah bagaimana perilaku informasi generasi millenial di Kota Semarang?

\section{Tujuan penelitian}

Tujuan dari penelitian ini adalah untuk menggambarkan perilaku informasi generasi millenial di Kota Semarang.

\section{Manfaat penelitian}

Manfaat penelitian ini secara teoritis akan menambah kebaruan pola perilaku informasi generasi millenial, dan secara praktis untuk menemukan pola perilaku informasi generasi millenial.

\section{Landasan teori}

Perilaku pencarian Informasi merupakan upaya menemukan dengan tujuan tertentu sebagai akibat dari adanya kebutuhan untuk memenuhi tujuan tertentu. Dalam upaya ini, seseorang dapat saja berinteraksi dengan sistem informasi hastawi (misalnya, surat kabar, majalah, perpustakaan), atau yang berbasis komputer (Wilson, 2000). Menurut Wilson (2000) dalam upaya pencarian informasi, seseorang bisa saja berinteraksi dengan sistem informasi manual (seperti surat kabar atau perpustakaan) atau dengan sistem 
berbasis-komputer, misalnya World Wide Web atau internet. Dalam model Wilson $(1981,1996)$ bahwa perilaku pencarian informasi berasal dari kebutuhan akan informasi oleh pengguna. Dan respon terhadap kebutuhan tersebut menuntut pada sistem informasi (seperti perpustakaan atau database), dan sumber informasi lainnya (seperti textbook, handout, dosen dan yang lainnya). Dan konteks kebutuhan informasi meliputi kebutuhan seseorang (mahasiswa) dan lingkungannya.

Ada sebuah teori perilaku pencarian informasi dari Khulthau (1991) yang menggambarkan kegiatan pencarian informasi sebagai sebuah proses konstruksi (pengembangan, pembangunan) yang dilalui seseorang dari tahap ketidak-pastian (uncertainly) menuju pemahaman (understanding). Ada 6 tingkatan atau langkah yang terkandung dalam proses konstruksi ini, yaitu: awalan (initiation), pemilihan (selection), penjelajahan (exploration), penyusunan (formulation), pengumpulan (collection), dan penyajian (presentation) (Pendit, 2006).

\section{Metode penelitian}

Metode penelitian yang digunakan dalam penelitian ini menggunakan pendekatan kualitatif. Pengumpulan data dengan menggunakan wawancara dan brainstorming kepada informan yang telah ditentukan kriterianya. Kriteria informan adalah remaja yang berusia 17 -19 tahun di Kota Semarang. Brainstorming dilakukan pada 5 informan yang berkumpul bersama dan berdiskusi membahas tentang bagaimana cara mereka menemukan kebutuhan informasi dan bagaimana mereka memenuhi kebutuhan informasi tersebut, yang dengan kata lain berarti mereka menggambarkan sebuah perilaku informasi.

\section{Hasil penelitian}

Model pencarian informasi generasi millenial dapat disampaikan dengan penjelasan bahwa generasi millenial mengawali proses pencarian informasi dengan sebuah pendorong yang membuat mereka bergerak melakukan serching atau browsing, kemudian generasi millenial melakukan seleksi akan informasi yang mereka dapatkan dengan cara memilih informasi yang sesuai dengan kebutuhan mereka. Kemudian generasi millenial melakukan evaluasi atas informasi yang mereka dapatkan, kemudian setelah mereka merasa bahwa informasi tersebut pantas untuk disebarluaskan maka mereka akan melakukan penyebarluasan atau akan membagi atau akan share infromasi tersebut. Kemudian setelah generasi tersebut melakukan share informasi maka mereka akan repost beberapa informasi yang mereka sukai, setelah itu mereka akan mengevaluasi kembali informasi yang direpost dan kemudian mereka akan melakukan respon atas segala informasi yang mereka dapatkan dan infromasi yang telah mereka share.

\section{a. Pendorong}

Pendorong merupakan sesuatu hal yang membuat generasi millenial ini bergerak. Para generasi millenial ini menggambarkan bahwa pendorong terkuat adalah trend yang mereka ikuti melalui dunia maya. Kecenderungan mengikuti trend tersebut membuat mereka tidak ingin ketinggalan

Copyright @2018, ISSN: 2598-3040 online 
dengan teman-temannya. Seperti halnya trend fashion yang memperlihatkan kacamata bundar dan kebiasaan memfoto semua kegiatan mereka. Atau seperti halnya kebiasaan mencampur berbagai varian baru dalam minuman mereka, jus dicampur dengan es krim dan coklat roll.

Kemudian pendorong mereka selanjutnya adalah hobby. Hobby merupakan kesukaan yang tidak bisa ditinggalkan. Generasi millenial menyatakan bahwa kesukaan mereka terkait teknologi dan manfaatnya tidak bisa ditinggalkan seperti kebiasaan foto memfoto, travelling dan berkumpul dengan teman-temannya.

Hal lain yang mendorong mereka adalah bakat. Generasi millenial memanfaatkan teknologi yang ada untuk menunjukkan bakat mereka, seperti halnya bakat menyanyi, generasi millenial menyalurkan hobby mereka lewat dunia maya/ youtube. Dengan fasilitas tersebut generasi millenial begitu percaya diri dengan mendulang icon like yang mereka dapatkan ketika bakat tersebut mereka share dalam akun mereka.

\section{b. Searching/Browsing}

Searching merupakan sebuah tindakan pencarian, dalam hal ini dapat diartikan sebagai sebuah tindakan atau perilaku yang membuat seseorang memulai mencari informasi yang dibutuhkan. Generasi millenial menamai tindakan atau perilaku ini dengan istilah yang beragam, ada yang memberi nama searching, ada yang memberi nama dengan istilah browsing dan ada yang menamai dengan istilah surfing. tentu ketiga istilah tersebut memiliki makna yang berbeda. Merujuk pada Kamus Bahasa Indonesia, searching diartikan dengan mencari, yang dimaksud adalah aktivitas mencari informasi dengan mesin pencari atau web search. Sedangkan browsing diartikan merawak, mengembara tetapi dengan agak terarah dalam mesin pencari seperti internet atau aktifitas mencari informasi dengan menggunakan aplikasi yang bernama web browser dalam jaringan internet.

Generasi millenial melakukan proses ini dengan cara menuliskan pencarian informasi sama persis dengan apa yang mereka pikirkan. Contoh : jika mereka mengenali pendorong mereka adalah teknik selfi maka mereka akan menuliskan sama persis dengan apa yang mereka pikirkan. Hal ini berbeda dengan proses pencarian informasi yang secara teori dijelaskan dapat memakai bolean logic atau dengan menggunakan pencarian dengan subjek atau dengan nama pengarang atau dengan nama judul buku atau berita tertentu.

Pencarian informasi dengan menggunakan bahasa yang kompleks sesuai dengan apa yang mereka pikirkan tetap juga berhasil karena bahasa indeks dalam database yang dibuat perkata, sehingga teknologi memang mampu mengakomodir dan mampu memberikan jawaban atas semua permintaan para pencari informasi. 


\section{c. Seleksi}

Seleksi merupakan tahapan memilih informasi yang dibutuhkan yang dilakukan generasi millenial. Dalam tahapan ini generasi millenial memilih dengan melihat semua hasil pencariannya, seperti ketika generasi millenial mencari informasi tentang teknik selfi, generasi digital ini akan melihat dahulu isi dari informasi tersebut, kemudian menimbang dengan beberapa faktor seperti kesediaan fasilitas dan kemungkinan dapat dilakukan atau tidak.

\section{d. Evaluasi}

Evaluasi merupakan tindangan menilai apakah informasi yang generasi digital dapatkan merupakan informasi yang benar, bermutu dan dapat dimanfaatkan. Beberapa cara yang dipakai oleh para generasi millenial ini adalah dengan melihat Sumber berita/ informasi, berdasarkan Pengakuan banyak orang, Tidak mudah percaya, Frekuensi share dan Informasi tersebut tidak berlebihan. Sedangkan verifikasi informasi yang dilakukan oleh digital native di Kota Semarang dengan cara melihat kolom komentar, cross check media informasi lain, bukti foto atau video, bukti yang jelas dari sumber primer, konfirmasi dan klarifikasi, membandingkan dan menyimpulkan serta merujuk pada web resmi.

\section{e. Share}

Share merupakan sebuah tindakan generasi millenial dalam menyebarkan atau membagi informasi yang mereka punya. Informasi yang disebarkan dapat berupa informasi akan dirinya sendiri atau informasi yang menurut generasi millenial benar dan bermanfaat. Penyebaran informasi pada media sosial akan semakin dominan jika semakin sering media sosial mengemukakan pendapat yang dominan di kalangan masyarakat maka semakin memudar atau melemah pendapat-pendapat di kalangan masyarakat yang menentang pendapat dominan.

\section{f. Repost}

Repost merupakan sebuah tindakan mengunggah ulang informasi yang pernah dibagi. Generasi millenial yang bercirikan sangat membanggakan identitas dirinya melakukan repost untuk informasi favorit mereka. Dalam tindakan ini generasi millenial akan menyeleksi informasi yang pernah mereka post yang memiliki respon like terbanyak dan pas sesuai dengan suasana hati mereka. Melalui repost tersebut generasi millenial menunjukkan eksistensi mereka.

\section{g. Evaluasi}

Evaluasi mereka lakukan kembali setelah tahapan repost yang telah mereka lakukan. Dengan evaluasi tersebut generasi millenial menimbang dan menilai informasi tersebut mendapatkan 
banyak komen ataukah tanggapan dari teman mereka. Jika mereka mendapatkan banyak tanggapan mereka akan merasa puas dan akan melanjutkan ke tahapan selanjutnya.

\section{h. Respon}

Respon merupakann tanggapan balik dari orang yang melihat dan memanfaatkan informasi dari generasi millenial. Respon dijadikan salah satu indikator diterimanya informasi yang disampaikan oleh generasi millenial tersebut.

\section{Penutup}

Kesimpulan yang dapat ditarik adalah tahapan perilaku pencarian informasi generasi millenial adalah dengan tahapan Pendorong, Searching/ Browsing/ Surfing, Seleksi, Evaluasi, Share, Repost, Evaluasi dan Respon.

\section{Referensi}

Puri, Chemmy Trias Sekaring. Pola Perilaku Penemuan Informasi (Information Seeking Behaviour) Mahasiswa Bahasa Asing di Universitas Airlangga. http://journal.unair.ac.id. Diakses tanggal 10 Nov 2018.

Pendit, Putu Laxman. 2006. Ragam Teori Informasi. http://eprints.rclis.org. Diakses tanggal 10 Nov 2018. 